\title{
Transcatheter implantation of atrial septal occluders in adult patients - evaluation of long-term outcome
}

Ocena odległych wyników przezskórnego leczenia ubytków w przegrodzie międzyprzedsionkowej i przetrwałych otworów owalnych u dorosłych pacjentów

\section{Ewa Kokocińska, Agnieszka Maicka, Jolanta Kolińska, Jarosław D. Kasprzak, Ewa Szymczyk, Radosław Kręcki, Łukasz Figiel, Jan Z. Peruga, Piotr Lipiec}

$2^{\text {nd }}$ Department of Cardiology, Medical University of Lodz, Poland

Post Kardiol Interw 2011; 7, 2 (24): 116-121 DOI: $10.5114 /$ pwki.2011.23163

\begin{abstract}
Background: Transcatheter closure of patent foramen ovale (PFO) and atrial septal defect (ASD) are procedures commonly performed in recent years.

Aim: To assess long-term results of percutaneous closure of ASD and PFO in adult patients.

Material and methods: The study group comprised 64 patients (45 women, mean age $50.5 \pm 12.7$ years), who in 2004-2010 underwent percutaneous closure of ASD or PFO. The occurrence of clinical end-points in the follow-up and possible changes in quality of life and echocardiographic parameters were taken into consideration.

Results: In a mean follow-up period of $310 \pm 305$ days there were no deaths or recurrent neurological or peripheral embolic events. In patients with PFO there was no minimal residual shunt immediately after the procedure in transthoracic and transoesophageal echocardiography, while in patients with ASD early closure of the shunt (up to $24 \mathrm{~h}$ ) was achieved in $64 \%$ of patients, and after 8 months of observation in $84 \%$. The majority of patients were free of complications after the procedure, but one patient underwent urgent surgery after dislocation of the device within $3 \mathrm{~h}$ of the procedure and two patients were diagnosed with new-onset atrial fibrillation (AF) about one month after the procedure. Telephone survey revealed that most patients ( $81 \%$ of patients with ASD and $29 \%$ of patients with PFO) noted a marked improvement in health status, relief of symptoms of heart failure, syncope and other symptoms experienced prior to the procedure.

Conclusions: Transcatheter closure of ASD and PFO is a safe and effective procedure. Moreover, a significant improvement of quality of life can be observed.
\end{abstract}

Key words: transcatheter closure, atrial septal defect, patent foramen ovale, septal occluder, quality of life

\section{Streszczenie}

Wstęp: W ostatnich latach coraz szerzej stosowane są przezskórne techniki leczenia przetrwałego otworu owalnego (ang. patent foramen ovale, PFO) oraz ubytków w przegrodzie międzyprzedsionkowej (ang. atrial septal defect, ASD).

Cel: Ocena odległych wyników przezskórnego zamknięcia ASD i PFO u dorosłych pacjentów.

Materiał i metody: Badaniem objęto 64 chorych (45 kobiet, średni wiek 50,5 $\pm 12,7$ roku), u których w latach 2004-2010 wykonano zabieg przezskórnego zamknięcia ASD lub PFO. Oceniano występowanie klinicznych punktów docelowych w obserwacji odległej, zmiany parametrów echokardiograficznych w kontrolnych badaniach przezklatkowych i przezprzełykowych oraz jakość życia pacjentów.

Wyniki: Średni czas obserwacji pacjentów po zabiegu wynosił $331 \pm 345$ i $267 \pm 202$ dni, odpowiednio u osób z ASD i PFO. W przypadku PFO nie obserwowano cech przecieku bezpośrednio po zabiegu w kontrolnym badaniu echokardiograficznym przezklatkowym i przezprzełykowym, natomiast u pacjentów z ASD wczesne całkowite zamknięcie przecieku (do 24 godz.) uzyskano u 64\%, a w obserwacji 8-miesięcznej u 84\% chorych. W obserwacji odległej u żadnego z pacjentów nie stwierdzono zgonu lub ponownego incydentu udarowego po zabiegu. U większości chorych nie zaobserwowano powikłań po zabiegu, w jednym przypadku doszło do przemieszczenia zapinki do prawej komory w ciągu 3 godz. od zabiegu, co spowodowało konieczność interwencji kardiochirurgicznej, natomiast u 2 osób rozpoznano świeże migotanie przedsionków około miesiąca po zabiegu. Telefoniczne badanie kwestionariuszowe

Corresponding author/Adres do korespondencji:

Assoc. Prof. Piotr Lipiec, 2nd Department of Cardiology, Medical University of Lodz, Wł. Bieganski Hospital, 1/5 Kniaziewicza, 91-347 Łódź, Poland, tel./fax: +48 4225160 15, e-mail: lipiec@ptkardio.pl

Praca wptynęła: 1.02.2011, przyjęta do druku: 20.05.2011. 
wykazało, że większość osób (81\% z ASD i 29\% z PFO) zauważyło wyraźną poprawę stanu zdrowia, ustąpienie objawów niewydolności serca, omdleń i innych dolegliwości odczuwanych przed zabiegiem.

Wnioski: Przezskórne zamknięcie ASD i PFO jest zabiegiem bezpiecznym i skutecznym. Ponadto obserwuje się istotną poprawę jakości życia pacjentów.

Słowa kluczowe: przezskórne zamknięcie, ubytek w przegrodzie międzyprzedsionkowej, przetrwały otwór owalny, okluder, jakość życia

\section{Introduction}

Atrial septal defect (ASD) and patent foramen ovale (PFO) are among the most frequent heart defects found in adult patients. Until the late 1970s surgical correction of the defect was a "gold standard" - now percutaneous closure of the defect with so-called "occluders" is used. The first procedure of occluder implantation was performed by King in 1976 [1].

Current guidelines of the European Society of Cardiology on the management of patients with congenital heart diseases published in 2010 qualify patients with ASD or PFO for percutaneous correction of the defect in the following situations: in patients with a significant leftto-right shunt (and with signs of right ventricular volume overload) and with vascular pulmonary resistance (PVR) $<5 \mathrm{mmHg} / \mathrm{l} / \mathrm{min}$ (Wood units - WU) irrespective of symptoms (class of recommendation IB); if feasible occluder implantation should be a method of choice in patients with ostium secundum ASD (class of recommendation IC). Qualification for the procedure should be considered in all patients with ASD and symptoms of paradoxical embolism (after exclusion of other causes) irrespective of the shunt size (class of recommendation $\mathrm{IlaC}$ ) and in patients with $\mathrm{PVR}>5 \mathrm{mmHg}$ but lower than $2 / 3$ of the systemic vascular resistance (SVR) or when pulmonary artery pressure (PAP) is lower than 2/3 of the SVR (at baseline or after provocation with vasodilatory drugs [nitric oxide preferred] or after targeted treatment of pulmonary hypertension) and when a significant left-to-right shunt defined by pulmonary to systemic flow ratio (Qp/Qs) > 1.5 is present (class of recommendations $\mathrm{IlbC}$ ) [2].

There are no univocal guidelines solving the clinical problem of qualification for the percutaneous closure of PFO as a secondary prophylaxis in patients after stroke. According to the American Heart Association and the American Stroke Association there are not sufficient data to recommend PFO closure in patients after the first stroke. Closure of the patent foramen ovale may be considered in patients with recurrence of cryptogenic stroke despite optimal treatment (class of recommendations IIbC) [3]. Ongoing multicentre controlled randomized trials (with a medical treatment arm) should help to establish the standard of care in patients with PFO (for example: PC-Trial - Patent foramen ovale and Cryptogenic embolism, RESPECT Clinical Trial - Randomized Evaluation of Recurrent Stroke comparing PFO Closure to Established Current Standard of Care Treatment, CLOSURE 1).
The aim of the study was to assess long-term results of percutaneous closure of ASD and PFO in adult patients including clinical endpoints, echocardiographic parameters and quality of life after the procedure.

\section{Material and methods}

The study group comprised 64 patients (45 women, 19 men, mean age $50.5 \pm 12.7$ years) who underwent percutaneous closure of ASD or PFO between 2004 and 2010 in the $2^{\text {nd }}$ Department of Cardiology of the Medical University of Łódź. Patients' characteristics are presented in table 1. Qualification for the procedure in patients with ASD was performed according to contemporary guidelines. Indications for percutaneous closure of the atrial septal defect included: detection of ostium secundum ASD of $>5 \mathrm{~mm}$ diameter with a concomitant haemodynamically significant left-to-right shunt (pulmonary to systemic flow ratio Qp/Qs > 1.5) or detection of ASD with right atrial or right ventricular dilation or coexisting paradoxical embolism [4]. Patent foramen ovale closure was attempted in patients with documented cryptogenic stroke. Recommendations implemented after the procedure are presented in table 2 .

The study included assessment of clinical endpoints in long-term observation and the change of echocardiographic parameters in control transthoracic (TTE) or transoesophageal (TEE) echocardiography (fig. 1).

The primary end-point was cardiovascular death or stroke/transient ischaemic attack (TIA). Secondary endpoints were the onset of heart failure symptoms, palpitations, syncope, peripheral or pulmonary embolism after the procedure and the need for cardiovascular

Table 1. Clinical characteristics of patients from the study group

Tabela 1. Charakterystyka kliniczna pacjentów z grupy badanej

Atrial septal Patent foramen defect $(n=44) \quad$ ovale $(n=20)$

\begin{tabular}{lcc}
\hline Age [years \pm standard deviation] & $52.8 \pm 13.3$ & $45.5 \pm 9.8$ \\
\hline Female sex & $32(73 \%)$ & $13(65 \%)$ \\
\hline Atrial fibrillation & $4(9 \%)$ & - \\
\hline Pulmonary hypertension & $4(9 \%)$ & - \\
\hline Pacemaker & $3(7 \%)$ & - \\
\hline $\begin{array}{l}\text { Previous stroke or transient } \\
\text { ischaemic attack }\end{array}$ & 0 & $20(100 \%)$ \\
\hline
\end{tabular}


Table 2. Recommendations after procedure

Tabela 2. Zalecenia po zabiegu

\begin{tabular}{ll} 
Atrial septal defect & Patent foramen ovale \\
\hline $\begin{array}{l}\text { 1. Acetylsalicylic acid (325 mg) for 6 months, clopidogrel (75 mg) } \\
\text { for 3 months }\end{array}$ & $\begin{array}{l}\text { 1. Acetylsalicylic acid (100 mg) for 6 months, clopidogrel (75 mg) } \\
\text { for 3 months }\end{array}$ \\
\hline $\begin{array}{l}\text { 2. Standard prophylaxis of infective endocarditis for 12 months } \\
\begin{array}{l}\text { 3. Systematic echocardiographic control (transthoracic } \\
\text { echocardiography) after 1, 3, 6, 12 months, then once a year }\end{array}\end{array}$ & $\begin{array}{l}\text { 2. Standard prophylaxis of infective endocarditis for 6 months } \\
\text { 3. Systematic echocardiographic control (transthoracic } \\
\text { echocardiography) next day, after 1, 3, } 6 \text { months and once a year }\end{array}$ \\
\hline $\begin{array}{l}\text { 4. Avoidance of intense physical efforts for a month } \\
\end{array}$
\end{tabular}
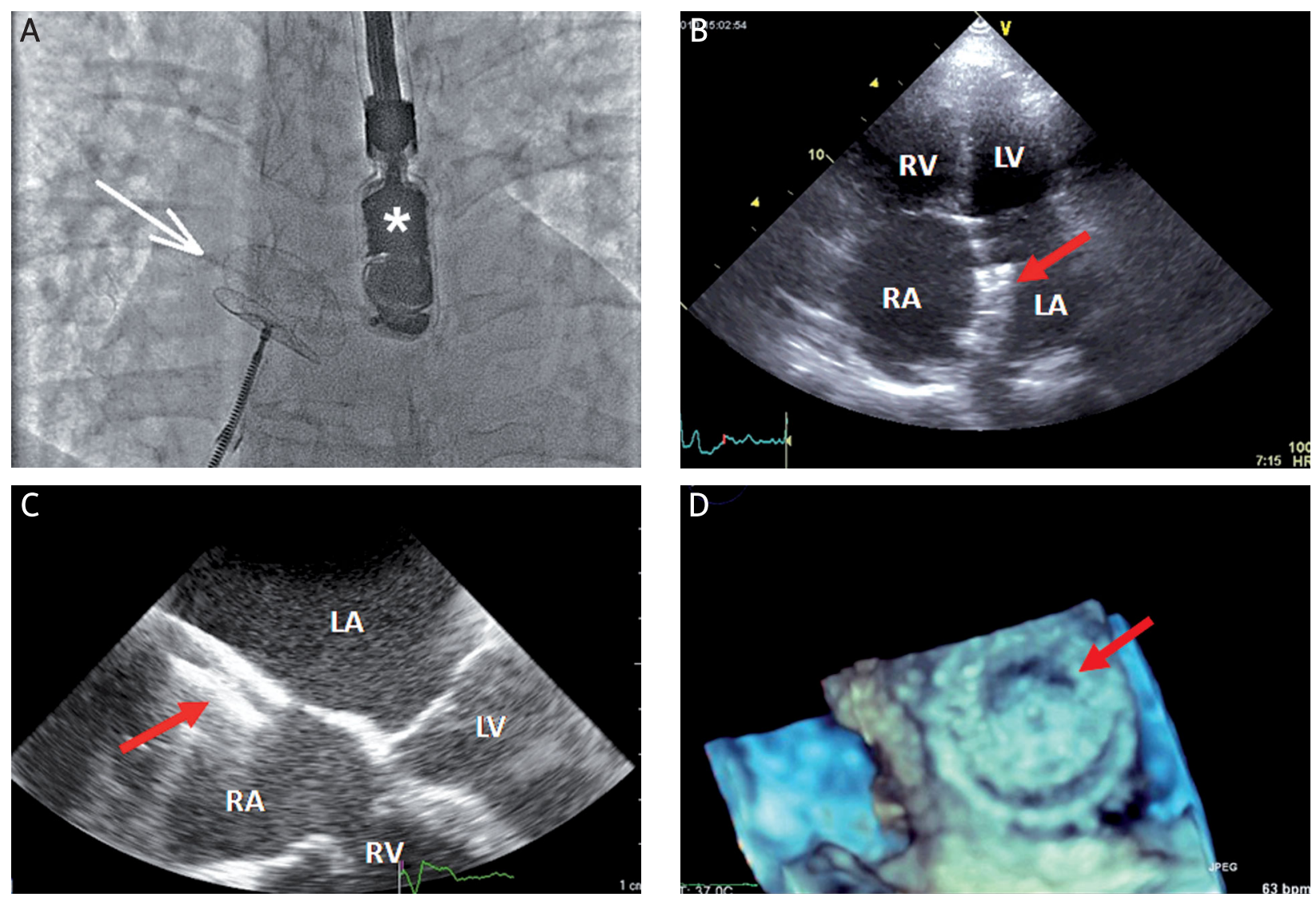

Fig. 1. A - fluoroscopy, LAO 30 view - implantation of Amplatzer ASD Occluder (arrow) in patient with ostium secundum atrial septal defect (type 2) under echocardiographic control (*transoesophageal echocardiographic transducer). B - transthoracic echocardiography (4-chamber apical view) in 72-year-old patient after closure of ostium secundum atrial septal defect (type 2) with Amplatzer $34 \mathrm{~mm}$ (arrow). C - transoesophageal echocardiography (modified 4-chamber view) in 78-year-old patient after closure of ostium secundum atrial septal defect (type 2) with Amplatzer $17 \mathrm{~mm}$ (arrow). D - three dimensional transoesophageal echocardiography in 57-year-old patient after closure of secundum atrial septal defect with Amplatzer $28 \mathrm{~mm}$ (arrow) - view from left atrium

$L A$ - left atrium, $L V$ - left ventricle, $R A$ - right atrium, $R V$ - right ventricle

Ryc. 1. A - fluoroskopia, projekcja LAO 30 - zabieg implantacji zapinki Amplatzer ASD Occluder (strzałka) u pacjenta z ubytkiem przegrody międzyprzedsionkowej (ASD) typu 2 pod kontrolą echokardiograficzną (* echokardiograficzna sonda przezprzełykowa). B - przezklatkowe badanie echokardiograficzne u 72-letniego pacjenta, u którego implantowano zapinkę Amplatzer $34 \mathrm{~mm}$ z powodu ASD typu 2. Na rycinie przedstawiono projekcję koniuszkową czterojamową - w obrębie przegrody międzyprzedsionkowej widoczne dyski zapinki (strzałka). C - przezprzełykowe badanie echokardiograficzne u 78-letniej pacjentki, u której implantowano zapinkę Amplatzer 17 mm z powodu ASD typu 2 w obrębie przegrody międzyprzedsionkowej widoczne dyski zapinki (strzałka). D - przezprzełykowe badanie echokardiograficzne trójwymiarowe (3D) u 57-letniego pacjenta, u którego implantowano zapinkę Amplatzer 28 mm z powodu ASD typu 2. Na rycinie przedstawiono dysk zapinki - widok od strony lewego przedsionka (strzałka) 
interventions. Patients underwent telephone survey including information on the changes in health status and the presence of symptoms after the procedure.

\section{Statistical analysis}

Continuous variables were assessed for normality of distribution with the Kolmogorov-Smirnov test. Variables with confirmed normal distribution were presented as mean and standard deviation and variables without confirmed normal distribution were presented as median and interquartile range. Student's t-test for unpaired samples was used to compare samples with normal distribution with significance level of $\alpha=0.05$ and Wilcoxon test was applied for samples without normal distribution with significance level of $\alpha=0.05$.

\section{Results}

Implantation of the occluder was successful in 64 patients (100\% of the studied group): closure of the ostium secundum ASD was performed in 44 patients (mean age $52.8 \pm 13.3$ years, $73 \%$ female) and closure of PFO was done in 20 patients (mean age $45.5 \pm 9.8$ years, $65 \%$ female) due to either previous cryptogenic stroke or TIA (tab. 3).

\section{Patients with atrial septal defect}

In patients with ASD mean time of observation after the procedure was $331 \pm 345$ days. Mean diameter of the implanted occluder was $25 \pm 7 \mathrm{~mm}$ (types: Amplatzer, Atriasept, Occlutech Figulla, Bio-Star, Intrasept, Helex).

Complete early closure of the shunt (up to $24 \mathrm{~h}$ ) was visualized on echocardiography in 28 of the 44 patients with ASD (64\%) and in 37 patients (84\%) in the long-term observation. A primary clinical endpoint did not occur in any of the patients in long-term follow-up. One of the patients developed atrial fibrillation (AF) about a month after the procedure, which persisted throughout the next control examinations.

In one of the patients (one of the initial cases performed in our centre; large ASD of $34 \mathrm{~mm}$ diameter) migration of the occluder into the right ventricle was shown on a TEE examination $3 \mathrm{~h}$ after the procedure. The patient was referred for emergency surgical treatment which led to ASD correction with good effect.

Control echocardiographic examinations performed at a mean of 331 days after the procedure showed a significant reduction of right atrial (RA) and right ventricular (RV) dimensions ( $p<0.001$ and $p<0.0001$ respectively) and decrease of Qp/Qs ratio ( $p=0.005)$ (tab. 4).

\section{Patients with patent foramen ovale}

Mean time of follow-up after the procedure was $267 \pm 202$ days. Mean diameter of the occluder was $24.6 \pm 4$ mm (types: Amplatzer, Atriasept, Occlutech Figulla, Intrasept, Helex). In the case of PFO there were no signs of shunt observed directly after the procedure in the TEE examination. There were no clinical endpoints in long-term observation in any of the patients. Echocardiographic parameters did not show significant changes at control examinations. In one of the patients the control examination performed one month after the procedure disclosed onset of atrial fibrillation.

\section{Quality of life assessment}

The telephone survey was conducted on a group of 48 patients (including 31 patients with ostium secundum atrial septal defect and 17 patients with patent foramen ovale). Symptoms before the procedure (such as syncope, dizziness, peripheral oedema, limitation of exercise tolerance, palpitations, dyspnoea) were present in 26 of the 31 patients with ASD (84\%). A marked improvement after percutaneous treatment of the defect was reported by 25 of them, which constitutes $96 \%$ of patients with ASD suffering from the described symptoms. The following symptoms were present in a small proportion of patients after the procedure: palpitations (in 13 patients with ASD $-42 \%$ and in 5 patients with PFO - 29\%) and syncope in 1 patient with PFO (6\%).

\section{Discussion}

Long-term results of percutaneous ASD and PFO treatment in our centre confirm the efficacy and safety of this method. The greatest benefits of ASD closure are seen

Table 3. Results of atrial septal defect and patent foramen ovale closure in the study group

Tabela 3. Wyniki zamknięcia ASD i PFO w grupie badanej

\begin{tabular}{|c|c|c|c|}
\hline & & $\begin{array}{l}\text { Atrial septal defect } \\
(n=44)\end{array}$ & $\begin{array}{l}\text { Patent foramen ovale } \\
\qquad(n=20)\end{array}$ \\
\hline \multicolumn{2}{|c|}{ Mean follow-up period [days \pm standard deviation] } & $331 \pm 345$ & $267 \pm 202$ \\
\hline \multicolumn{2}{|c|}{ Occluder size [mm \pm standard deviation] } & $25 \pm 7$ & $24.6 \pm 4$ \\
\hline \multirow[t]{2}{*}{ Total closure of shunt } & Early $(<24 \mathrm{~h})$ & $28(64 \%)$ & - \\
\hline & Late (up to 12 months after implantation) & $37(84 \%)$ & - \\
\hline \multicolumn{2}{|c|}{ Migration of occluder to right ventricle } & $1(2.3 \%)$ & 0 \\
\hline \multicolumn{2}{|c|}{ Stroke or transient ischaemic attack (new) } & 0 & 0 \\
\hline \multicolumn{2}{|l|}{ Atrial fibrillation (new) } & $1(2.3 \%)$ & $1(5 \%)$ \\
\hline
\end{tabular}


Table 4. Echocardiographic parameters before and after the procedure - patients with atrial septal defect

Tabela 4. Parametry echokardiograficzne przed zabiegiem i po zabiegu - pacjenci z ASD

\begin{tabular}{|c|c|c|c|}
\hline $\begin{array}{l}\text { Parameter } \\
\text { (mean } \pm \text { standard deviation) }\end{array}$ & Before & After & Value of $p$ \\
\hline $\mathrm{RA}[\mathrm{mm}]$ & $45.6 \pm 7.8$ & $41.7 \pm 6.6$ & $<0.001$ \\
\hline $\mathrm{RV}[\mathrm{mm}]$ & $36 \pm 6.6$ & $31 \pm 5.1$ & $<0.0001$ \\
\hline $\mathrm{PA}[\mathrm{mm}]$ & $29.2 \pm 6.3$ & $27.3 \pm 4.4$ & 0.1385 \\
\hline $\mathrm{LA}[\mathrm{mm}]$ & $41.6 \pm 6.6$ & $42 \pm 5.9$ & 0.3388 \\
\hline Qp/Qs & $2 \pm 0.8$ & $1.3 \pm 0.35$ & 0.005 \\
\hline TV Vmax $[\mathrm{m} / \mathrm{s}]$ & $0.7(0.6,1.1)$ & $0.64 \pm 0.17$ & - \\
\hline$P V \vee \max [\mathrm{m} / \mathrm{s}]$ & $1.2(0.9,2.0)$ & $1 \pm 0.2$ & - \\
\hline \multicolumn{4}{|c|}{$\begin{array}{l}R A \text { - right atrium, RV-right ventricle, } P A \text { - pulmonary artery, } L A \text { - left } \\
\text { atrium, } Q p / Q s \text { - pulmonary to systemic flow ratio, TV Vmax - maxi- } \\
\text { mal tricuspid valve flow, } P V \text { Vmax-maximal pulmonary valve flow } \\
R A \text { - prawy przedsionek, } R V \text { - prawa komora, } P A \text { - pień płucny, } \\
L A \text { - lewy przedsionek, } Q p / Q s \text { - stosunek przepływu płucnego do sys- } \\
\text { temowego, TV Vmax - maksymalny przeptyw przez zastawkę trójdziel- } \\
\text { na, } P V V \text { max - maksymalny przeptyw przez zastawkę płucną }\end{array}$} \\
\hline
\end{tabular}

in patients with defect correction performed before 25 years of age [2]. Nevertheless, the benefits of occluder implantation for the patients are significant irrespective of their age and include a limitation of: dyspnoea, exercise intolerance, development of pulmonary hypertension and finally right ventricular failure. According to current guidelines percutaneous closure is a preferred method of treatment [2].

Often there is a small residual shunt present directly after the procedure, which has been confirmed by the results from other centres [5]. Nevertheless, the true effectiveness of the procedure should be based on late complete shunt cessation, which was found in 37 out of 44 patients (84\%) with ASD at 8 months follow-up. In patients with patent foramen ovale correction of the defect is an efficacious method of secondary prophylaxis of thromboembolic incidents, which is confirmed by the fact that there were no new strokes or transient ischaemic attacks in the studied group [6]. Reports from other centres show a direct procedure efficacy of $86-100 \%$ with recurrence of thromboembolic incidents in $0-4.9 \%$ of patients in the long-term control examinations [6-8]. There were no recurrent thromboembolic events in the presented group.

The described procedure is safe, which was also reported by other centres $[9,10]$. However, in certain situations complications may appear. Quite early after introduction of this method it was suggested that percutaneous treatment of the defect may be complicated by arrhythmia. Hill and collaborators demonstrated the occurrence of supraventricular arrhythmia after the procedure, which justifies the long-term follow-up of patients for possible onset of arrhythmia [11]. Studies performed in one of the Polish centres showed that percutaneous closure of atrial septal defects may lead to onset of tachy- or bradyarrhythmia in around $1.5 \%$ of patients (11 of 739 patients who underwent the procedure) [12]. Also in our group the onset of atrial fibrillation was demonstrated in 2 patients (3\%). Despite documented safety the procedure may lead to potentially severe complications such as occluder migration which requires surgical intervention [9]. There was one case of occluder migration in the presented group.

In our material as in previous reports it can be noted that percutaneous closure of ASD leads to reduction of heart cavity dimensions, improvement of right and left ventricular function and improvement of haemodynamic parameters. These changes are not only related to the cessation of symptoms but also have a protective effect against the onset of supraventricular arrhythmias [13].

Quality of life of the patients is a significant part of the procedure efficacy assessment. As demonstrated by the studies ASD leads to various symptoms, which was also confirmed by our study: $84 \%$ of patients reported clinical symptoms before the correction of the defect (26 of the 31 patients with ASD included in the telephone survey) [14]. As many as $96 \%$ of patients ( 25 of the 31 patients from the survey group) reported cessation or attenuation of symptoms after the procedure. Additionally, patients declared a marked quality of life improvement after the occluder implantation related not only to the cessation of clinical symptoms but also to a significantly lower fear of possible disease complications such as stroke or TIA.

\section{Conclusions}

The study showed that the procedure of percutaneous closure of ASD and PFO is safe, effective and well tolerated by the patients.

\section{References}

1. King TD, Mills NL. Nonoperative closure of atrial septal defects. Surgery 1974; 75: 383-388.

2. Baumgartner H, Bonhoeffer P, De Groot NM, et al. ESC Guidelines for the management of grown-up congenital heart disease (new version 2010). Eur Heart J 2010; 31: 2915-2957.

3. Sacco RL, Adams R, Albers G, et al. Guidelines for prevention of stroke in patients with ischemic stroke or transient ischemic attack: a statement for healthcare professionals from the American Heart Association/American Stroke Association Council on Stroke: co-sponsored by the Council on Cardiovascular Radiology and Intervention. Circulation 2006; 113: e409-e449.

4. Warnes CA, Williams RG, Bashore TM, et al. ACC/AHA 2008 guidelines for the management of adults with congenital heart disease. J Am Coll Cardiol 2008; 52: e143-e263.

5. Chan KC, Godman MJ, Walsh K, et al. Transcatheter closure of atrial septal defect and interatrial communications with a new self expanding nitinol double disc device (Amplatzer septal occluder): multicentre UK experience. Heart 1999; 82: 300-306. 
6. Hong TE, Thaler D, Brorson J, et al. Transcatheter closure of patent foramen ovale associated with paradoxical embolism using the amplatzer PFO occluder: initial and intermediate-term results of the U.S. multicenter clinical trial. Catheter Cardiovasc Interv 2003; 60: 524-528.

7. Windecker S, Wahl A, Nedeltchev K, et al. Comparison of medical treatment with percutaneous closure of patent foramen ovale in patients with cryptogenic stroke. J Am Coll Cardiol 2004; 44: 750-758.

8. Windecker S, Wahl A, Chatterjee T, et al. Percutaneous closure of patent foramen ovale in patients with paradoxical embolism: longterm risk of recurrent thromboembolic events. Circulation 2000; 101: 893-898.

9. Chessa M, Carminati M, Butera G, et al. Early and late complications associated with transcatheter occlusion of secundum atrial septal defect. J Am Coll Cardiol 2002; 39: 1061-1065.
10. Dardas PS, Ninios VN, Mezilis NE, et al. Percutaneous closure of atrial septal defects: immediate and mid-term results. Hellenic J Cardiol 2010; 51: 104-112.

11. Hill SL, Berul Cl, Patel HL, et al. Early ECG abnormalities associated with transcatheter closure of atrial septal defects using the Amplatzer septal occlude. J Interv Card Electrophysiol 2000; 4: 469-474.

12. Szkutnik M, Lenarczyk A, Kusa J, et al. Symptomatic tachy- and bradyarrhythmias after transcatheter closure of interatrial communications with Amplatzer devices. Cardiol J 2008; 15: 510-516.

13. Salehian O, Horlick E, Schwerzmann M, et al. Improvements in cardiac form and function after transcatheter closure of secundum atrial septal defects. J Am Coll Cardiol 2005; 45: 499-504.

14. Rostad H, Sörland S. Atrial septal defect of secundum type in patients under 40 years of age. A review of 481 operated cases. Symptoms, signs, treatment and early results. Scand J Thorac Cardiovasc Surg 1979; 13: 123-127. 